\title{
Calcium signalling in the ciliated protozoan model, Paramecium: Strict signal localisation by epigenetically controlled positioning of different $\mathrm{Ca}^{2+}$-channels
}

\author{
Helmut Plattner* \\ Department of Biology, University of Konstanz, P.O. Box M625, 78457 Konstanz, Germany
}

\begin{abstract}
A B S T R A C T
The Paramecium tetraurelia cell is highly organised, with regularly spaced elements pertinent to $\mathrm{Ca}^{2+}$ signalling under epigenetic control. Vesicles serving as stationary $\mathrm{Ca}^{2+}$ stores or undergoing trafficking contain $\mathrm{Ca}^{2+}$-release channels (PtCRCs) which, according to sequence and domain comparison, are related either to inositol 1,4,5-trisphosphate ( $\left.\operatorname{InsP}_{3}\right)$ receptors $\left(\mathrm{IP}_{3} \mathrm{R}\right)$ or to ryanodine receptor-like proteins (RyR$\mathrm{LP}$ ) or to both, with intermediate characteristics or deviation from conventional domain structure. Six groups of such PtCRCs have been found. The ryanodine-InsP $\mathrm{P}_{3}$-receptor homology (RIH) domain is not always recognisable, in contrast to the channel domain with six trans-membrane domains and the pore between transmembrane domain 5 and 6. Two CRC subtypes tested more closely, PtCRC-II and PtCRC-IV, with and without an $\mathrm{InsP}_{3}$-binding domain, reacted to $\mathrm{InsP}_{3}$ and to caffeine, respectively, and hence represent $\mathrm{IP}_{3}$ Rs and RyR-LPs. $\mathrm{IP}_{3}$ Rs occur in the contractile vacuole complex where they allow for stochastic constitutive $\mathrm{Ca}^{2+}$ reflux into the cytosol. RyR-LPs are localised to cortical $\mathrm{Ca}^{2+}$ stores; they are engaged in dense core-secretory vesicle exocytosis by $\mathrm{Ca}^{2+}$ release, superimposed by $\mathrm{Ca}^{2+}$-influx via non-ciliary $\mathrm{Ca}^{2+}$ channels. One or two different types of PtCRCs also occur in other vesicles undergoing trafficking. Since the PtCRCs described combine different features they are considered derivatives of primitive precursors. The highly regular, epigenetically controlled design of a Paramecium cell allows it to make $\mathrm{Ca}^{2+}$ available very locally, in a most efficient way, along predetermined trafficking pathways, including regulation of exocytosis, endocytosis, phagocytosis and recycling phenomena. The activity of cilia is also regulated by $\mathrm{Ca}^{2+}$, yet independently from any CRCs, by de- and hyperpolarisation of the cell membrane potential.
\end{abstract}

\section{Introduction - Paramecium, a highly organised cell under epigenetic control}

The ciliated protozoan, Paramecium tetraurelia, is a highly organised cell with a regular arrangement of organelles over almost the entire cell surface [1,2], as documented by R.D. Allen at http://www.5.pbrc.hawaii.edu/allen/[3] and outlined in Fig. 1. This includes cilia, dense core-secretory organelle (trichocyst) docking sites, cortical $\mathrm{Ca}^{2+}$ stores (alveolar sacs), clathrin-coated endocytosis sites (parasomal sacs) located laterally to ciliary bases, and early endosomes (terminal cisternae) located below basal bodies. They constitute repetitive units of the surface area, the kinetids. Each kinetid harbours one cilium (or two in a small area), a parasomal sac, a terminal cisterna, a trichocyst and an alveolar sac (underlying half part of two adjacent kinetids); the size of a kinetid is

\footnotetext{
* Tel.: +49 753188 2228; fax: +49 7531882168 .

E-mail address: helmut.plattner@uni-konstanz.de
}

$\sim 2.0 \mu \mathrm{m} \times 1.7 \mu \mathrm{m}[4]$, and there are fixed distances for each of the respective substructures.

This regular cortex structure is under epigenetic control in Paramecium [5,6] and in Tetrahymena [7,8], as became evident from the transgenerational transmission of inverted cortex structure after incomplete separation of conjugants or after microsurgery. In addition, there are some other duplicate or single structures located at invariable sites: two contractile vacuole complexes, serving for the regulation of ion and water homeostasis, are attached to specific sites of the dorsal cell membrane. The site of phagosome formation, i.e. the oral cavity (with cytostome and cytopharynx), as well as the site of release of spent food vacuoles (phago[lyso]somes), the cytoproct, are both located at the ventral side, also at predetermined sites, as is the trafficking route for vesicles recycling from the cytoproct to the cytopharynx $[1,9,10]$.

Clearly the basic principles of $\mathrm{Ca}^{2+}$ signalling have been developed already early in the evolution of the eukaryotic cell $[11,12]$ and, thus, also in ciliated protozoa such as Paramecium [13]. The evolution of ciliated protozoa started about one billion years ago 


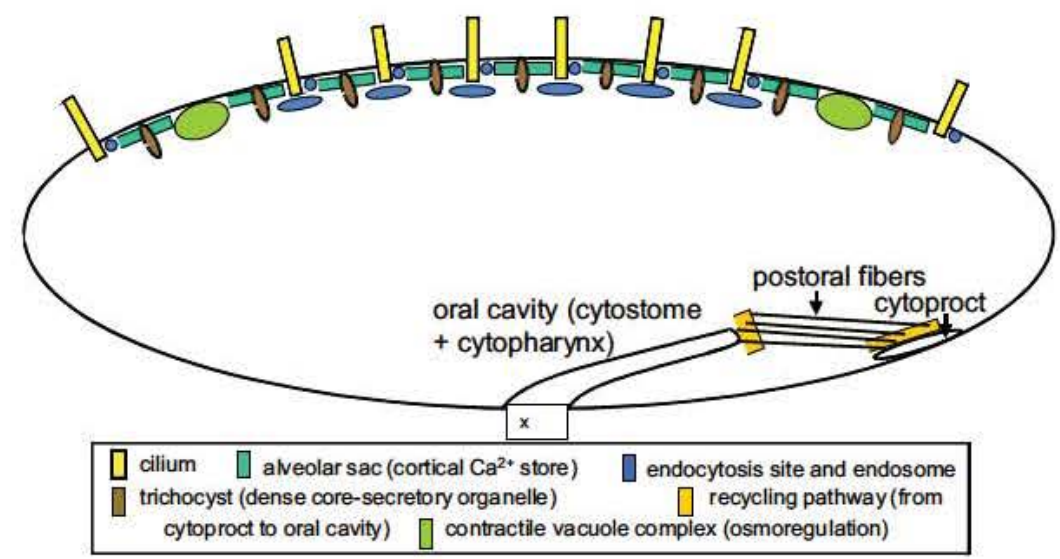

Fig. 1. Epigenetically controlled regular arrangement of surface components in a Paramecium cell. Note the regular arrangement of cilia, calcium stores (alveolar sacs), endocytosis sites (parasomal sacs) and early endosomes (terminal cisternae) in the cell cortex. In addition, note the fixed arrangement of trafficking pathways for recycling vesicles from the cytoproct to the oral cavity after release of the contents of spent food vacuoles (phago[lyso]somes). This route is supported by microtubular arrays (postoral fibres). For further explanations, see text.

[14-16], i.e. around the time of radiation of multicellular organisms. $\mathrm{Ca}^{2+}$ signalling occurs in protozoa of both groups, unikonts (Amorphea, including myxamoebae such as Dictyostelium) and bikonts (Stramenopila, including ciliates such as Paramecium). The first line of evolution led to metazoa, the second line of phylogeny culminates in green plants $[17,18]$. In fact, most data available for $\mathrm{Ca}^{2+}$ signalling in protozoa are from Dictyostelium and Paramecium, respectively.

Epigenetic control, particularly of cell surface pattern formation, is a salient feature of ciliates. Currently particularly this feature makes this group an interesting model for cell biologists $[19,20]$. On this basis we now envisage two main aspects. First, what is the spectrum of $\mathrm{Ca}^{2+}$ signalling mechanisms in ciliated protozoa? Second, to what extent may their regular, epigenetically controlled structural design be of any relevance for efficient $\mathrm{Ca}^{2+}$ signalling? In this context we shall briefly address plasmalemmal Ca ${ }^{2+}$-channels and then focus on intracellular $\mathrm{Ca}^{2+}$-release channels (CRC).

\section{Regular surface pattern of the Paramecium cell and potential advantages for $\mathrm{Ca}^{2+}$ signalling - background information}

As seen in an electron micrograph obtained from cell cortex fragments, isolated from $P$. tetraurelia cells and negatively stained (Fig. 2), ciliary basal bodies are arranged in regular intervals, as are docking sites for trichocysts. Alveolar sacs are closely attached, side-by-side, to the cell membrane, also in a regular pattern. These very flat sacs represent cortical $\mathrm{Ca}^{2+}$ stores [21] from where $\mathrm{Ca}^{2+}$ is mobilised during exocytosis stimulation, but not during any kind of ciliary activity $[13,22]$. Kinetids are not only distinct structural, but also functional subunits. The $\sim 3000$ kinetids per cell [4] are arranged in longitudinal rows, the kineties.

Which consequences does this regular design entail for $\mathrm{Ca}^{2+}$ signalling? First, the cell can activate, for instance, exocytosis sites individually or over large areas, thus producing a considerable amplification and synchronisation [23]. Second, the regular arrangement of cilia is prerequisite to their functional coupling during normal beat whereby collectively the beat pattern takes place in metachronal waves [24]. Even normal beat requires a basal $\left[\mathrm{Ca}^{2+}\right]$ and its increase accelerates beat frequency [25]. Based on specific $\mathrm{Ca}^{2+}$ signals, in response to specific exogenous signals, ciliary activity can be synchronously altered. This includes mechanical or chemical stimuli as well as depolarisation or hyperpolarisation of the membrane potential [26].
Two specific sites serve for the attachment of a pair of contractile vacuole complexes and these contractile complexes themselves are also sites of intense $\mathrm{Ca}^{2+}$ signalling [27]. In addition, the cell evidently requires $\mathrm{Ca}^{2+}$ signals at the oral cavity (cytostome and cytopharynx) for phagosome/food vacuole formation by vesicle delivery, as well as at the cytoproct for vesicle recycling after the release of undigested materials (Fig. 1), as one may derive from the occurrence of CRCs in the vesicles associated with the cytopharynx and the cytoproct [28]. This is also true for parasomal sacs which, together with terminal cisternae, are at the beginning of an endocytotic vesicle trafficking pathway; as mentioned, both structures are firmly installed under epigenetic control at fixed positions. In metazoan cells endocytosis also depends on $\mathrm{Ca}^{2+}[29,30]$.

Until the 19 hundred nineties, analysis of $\mathrm{Ca}^{2+}$ signalling in ciliates was restricted to ciliary activity, based mainly on electrophysiology of the Paramecium cell. Comparison of deciliated cells with normal control cells enabled the localisation and characterisation of many ion channels in the ciliary and non-ciliary (somatic) cell membrane [26]; see Fig. 3(A and B). In fact, channels determining ciliary activity exhibit a bimodal distribution. As outlined below, those giving the command (receptor potential) for changing beat direction are positioned separate from those executing the command (action potential) [26]. Many of them are sensitive to the intracellular free $\mathrm{Ca}^{2+}$ concentration $\left[\mathrm{Ca}^{2+}\right]_{i}$, just adjacent to the cell membrane, or rather to $\mathrm{a} \mathrm{Ca}^{2+} /$ calmodulin complex [26,31-33], and they may conduct $\mathrm{Ca}^{2+}$ themselves. A receptor potential is formed upon de- or hyperpolarisation, depending on the type of mechanosensitive channels activated. These are $\mathrm{Ca}^{2+}$-influx channels, and $\mathrm{K}^{+}$-efflux channels, respectively, and, in consequence, some additional channels are activated [26,31,34]. Each of these channel types is differentially localised; those initiating de- and hyperpolarisation are arranged in the somatic cell membrane in a gradient rising from the mid of the cell to the anterior and posterior apex, respectively (Fig. 3). See Refs. [26,31-33] for detailed reviews on electrophysiology and ref. [35] for partial molecular characterisation of some of these channels.

Thus, the receptor potential generated by the activation of the respective channels in the somatic cell membrane leads to an activation potential and a defined behavioural response. This implies the reversal of the ciliary beat direction (ciliary reversal) and accelerated forward swimming, respectively, depending on whether the cell has been de- or hyperpolarized. Following depolarisation, ciliary reversal is activated by $\mathrm{Ca}^{2+}$-influx into cilia via voltage-dependent $\mathrm{Ca}^{2+}$-channels which are restricted to the 


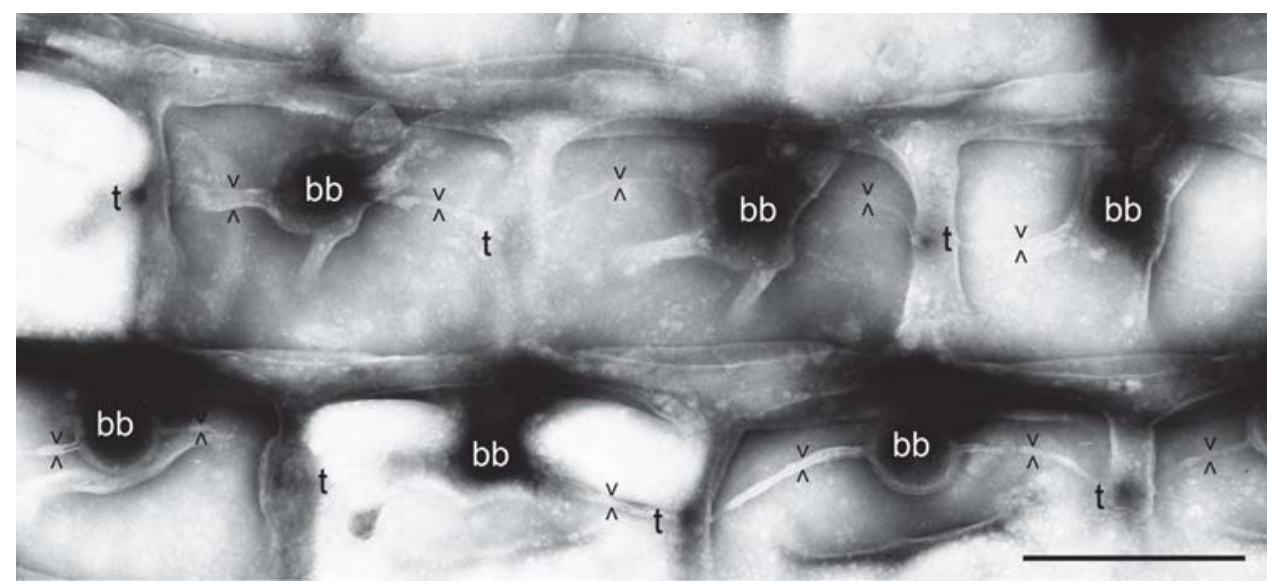

Fig. 2. Electron micrograph of an isolated Paramecium cell cortex fragment visualised by negative staining. Note the regular arrangement of unit surface fields (kinetids), arranged in longitudinal lines (kineties) within an egg-case type cell surface relief. It displays cilia (bb = basal bodies) alternating with trichocyst attachment sites ( $\mathrm{t}$ ). Along the $\mathrm{bb} / \mathrm{t}$ line adjacent alveolar sacs are seen, with borders between arrowheads. Note that cilia and trichocysts have been removed during isolation of cell cortex fragments. Unpublished micrograph from the series published by Bilinski et al. [100]. Scale bar $=1 \mu \mathrm{m}$.

ciliary membrane [36]; see Fig. 3(A and B). This reaction helps the cell to avoid struggling with obstacles and spoiling energy, before it resumes normal forward swimming. Alternatively, enhanced forward swimming enables the cell to follow molecular traces of bacterial food, such as folic acid and biotin in a positive chemoresponse/chemotaxis [37-39]. Similarly ciliary reversal is also the basis of negative chemoresponses/chemotaxis. Both, positive and negative chemotaxis are regulated by $\mathrm{Ca}^{2+}$, though in different ways, by different ion conductances. Such pile-up to a synchronous response is enabled by the regular arrangement of cilia. Clearly epigenetically determined spacing of cilia is mandatory not only for normal coordinated beat activity but also for coordinated ciliary responses "upon command". Positioning of cilia in a precise pattern and spacing is of evolutionary advantage as it allows for hydrodynamic coupling of the ciliary response by adhesive forces [24].

In $P$. tetraurelia, $\mathrm{Ca}^{2+}$ stores containing $\mathrm{Ca}^{2+}$-release channels (PtCRCs) do not contribute to ciliary beat activity. They are not directly amenable to electrophysiology and they have received attention only quite recently. They are, in part, also arranged in regular patterns to optimise signalling, as to be discussed below.

\section{Types of $\mathrm{Ca}^{2+}$-channels in Paramecium and their subcellular distribution}

Fig. 4(A-C) outlines the types of PtCRCs which are related to $\mathrm{IP}_{3} \mathrm{Rs}$ and RyRs according to overall similarity, domain analysis, subcellular localisation, analysis of the pore domain contained in its transmembrane region etc., as described in detail previously [28]. Eventually this was supported by functional analysis including gene silencing, as well as by biochemical and $\mathrm{Ca}^{2+}$ fluorochrome analysis $[40,41]$. We found a total of 39 of such channels, grouped in 6 subfamilies.

The activation mechanism has been experimentally determined only with PtCRC-II and PtCRC-IV. PtCRC-II binds the correct stereoisomer of InsP $\mathrm{P}_{3}$, Ins 1,4,5-trisphosphate [28]; modelling of its Ins: $\mathrm{P}_{3}$-binding domain largely coincides with that of mammalian homologues. In situ activation of caged $\mathrm{InsP}_{3}$ changes pattern of $\mathrm{Ca}^{2+}$ signals which constitutively/spontaneously emerge along the contractile vacuole complex. In contrast, PtCRC-IV is activated by the RyR agonists, caffeine and 4-chloro-meta-cresol [41]. Because of some deviation from classical RyRs familiar from metazoans, they should better be called RyR-LPs. Any other types of the PtCRCs we found await scrutiny.
Applying up-to-date programmes we determined consistently 6 transmembrane domains in the carboxy-terminal region in all PtCRC sequences and a selectivity filter with the aminoacid sequences Gly-Val-Gly-Asp and Gly-Ile-Gly-Asp [28], as known from $\mathrm{IP}_{3} \mathrm{Rs}$ and RyRs in metazoans, but with some deviations, as will be discussed below.

\section{Functional and evolutionary implications and comparison with other systems}

During evolution, the arrangement of cilia and their $\mathrm{Ca}^{2+}$ dynamics has changed. For instance, in metazoans one finds no comparable regularity of the surface pattern, including the arrangement of cilia. Hypothetically, during evolution of ciliated protozoa, the regular arrangement of cilia may have served as a scaffold for the coassembly of additional elements that now form a kinetid. In one way or another all structures composing a kinetid are involved in $\mathrm{Ca}^{2+}$ signalling; for instance, as documented in Fig. 5, parasomal sacs contain an unexpectedly high number of CRCs, type PtCRC-V-4 with an InsP $\mathrm{P}_{3}$-binding domain [28]. The functional significance of these very abundant channels is as uncertain as that of the extremely small numbers, less than three, of $\mathrm{IP}_{3}$ Rs detected in the cell membrane of some mammalian cells [42]. In Paramecium, these channels could account for the ill defined non-selective, high conductance channels responsible for leaking conductances registered by electrophysiologists [26]. Such channels may provide a Paramecium cell with sufficient $\mathrm{Ca}^{2+}$ under natural conditions, although under laboratory conditions the opposite, i.e. elimination of an excess of $\mathrm{Ca}^{2+}$, appears more significant.

The highly organised cell surface pattern can mediate a clear local response to a local stimulus, e.g. a secretatogue. Stimulation of larger areas causes a pile-up of synchronous responses [23,43]. Nevertheless, differential $\mathrm{Ca}^{2+}$ responses can activate selectively one or another activity in the Paramecium cell cortex. An example is the $\mathrm{Ca}^{2+}$ signal that triggers a ciliary reversal response without triggering trichocyst exocytosis at the same time.

In each case it is not only functionally, but also energetically favourable to have the source and the respective target of $\mathrm{Ca}^{2+}$ in close proximity, particularly also because the signal and its efficiency decay very rapidly with distance $[44,45]$. Possible epigenetic mechanisms mediating such strict confinement of signalling have been discussed somewhere else [20]. There are good reasons to speculate that $\mathrm{Ca}^{2+}$ may even be part of the epigenetic signals leading to the formation of the regular cell surface pattern [27]. 

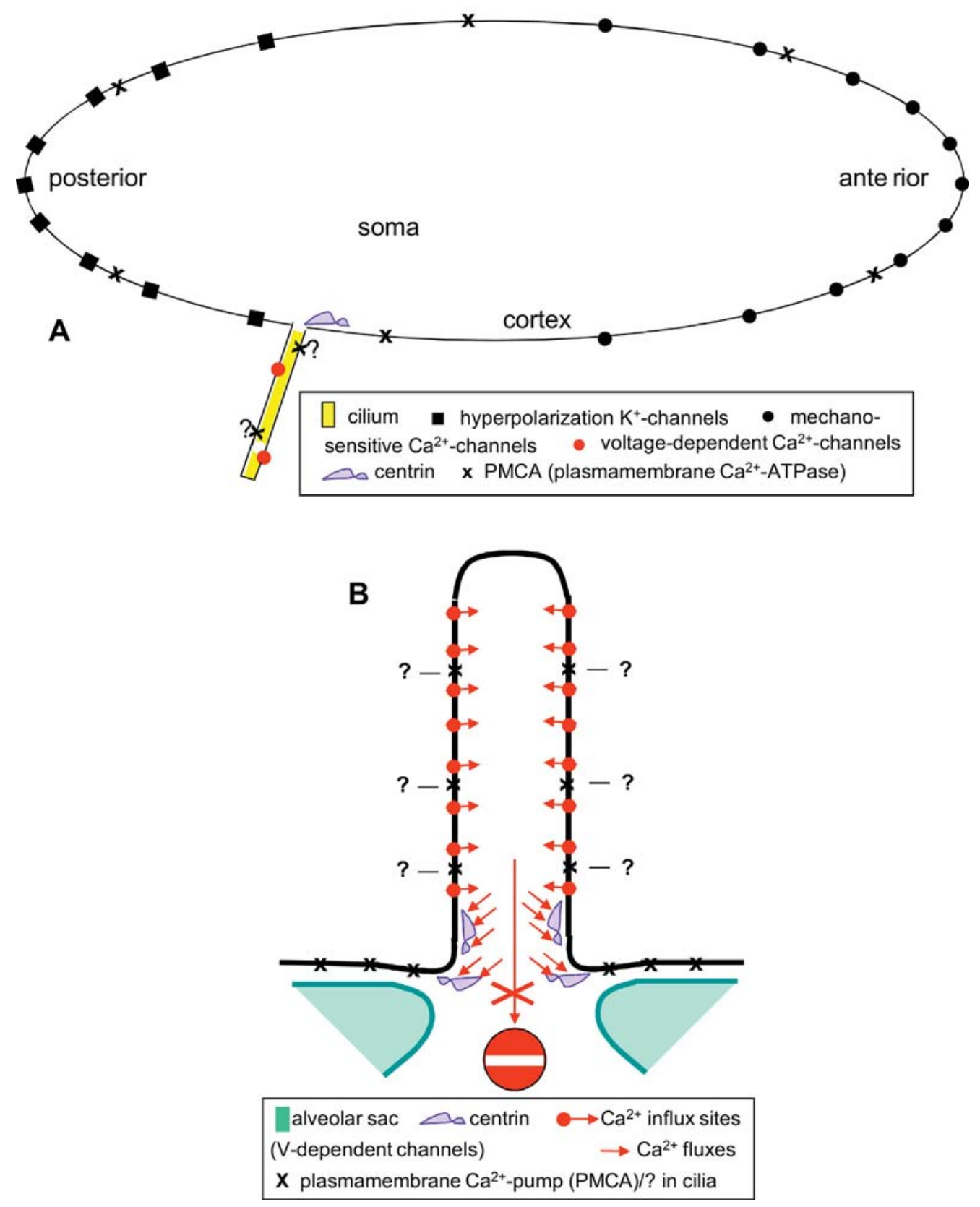

Fig. 3. Cation-channels relevant for ciliary activity in Paramecium. (A) Channels pertinent to the regulation of ciliary activity. Note anterior enrichment of mechanosensitive depolarisation channels and posterior enrichment of hyperpolarisation channels (see text). They are both restricted to the somatic (non-ciliary) cell membrane, each type with a gradient evanescent towards the middle of the cell. Also note restriction of voltage-dependent $\mathrm{Ca}^{2+}$-influx channels to ciliary membranes. Cortical localisation of centrin, including basal regions of cilia, is also important for $\mathrm{Ca}^{2+}$ signalling (for details, see text). The occurrence of a PMCA-type Ca ${ }^{2+}$-ATPase/pump in the somatic cell membrane is certain, but unsettled for the ciliary membrane. (B) Scheme of a cilium summarising $\mathrm{Ca}^{2+}$ fluxes pertinent to ciliary reversal. Note distribution of voltage-dependent $\mathrm{Ca}^{2+}$-channels over the entire cilium and "trapping" of $\mathrm{Ca}^{2+}$ by centrin located at and near the ciliary basis. Again the occurrence of a PMCA-type Ca ${ }^{2+}$-ATPase/pump for the somatic cell membrane has been ascertained, but is unsettled for the ciliary membrane. Note the absence of $\mathrm{Ca}^{2+}$ spill-over into the soma and the fact that alveolar sacs do not normally contribute to the regulation of ciliary activity during ciliary reversal (for exceptions, see text).

\subsection{Cilia}

For enduring swimmers, such as ciliates, it is important that spacing of cilia is appropriate to guarantee hydrodynamic coupling in metachronal waves [24]. It is also important to draw consequences when running against an obstacle and ciliary reversal serves just for this purpose. How has this mechanism been optimised?

Voltage-dependent $\mathrm{Ca}^{2+}$-channels also regulate the activity of cilia in ciliates other than Paramecium [26] and in ctenophores [46], but not in higher metazoans. For instance, $\mathrm{Ca}^{2+}$-channels responsible for the activity of the primary cilium in mammalian cells are functionally different and not restricted to the cilium [47].

As mentioned, in Paramecium voltage-dependent $\mathrm{Ca}^{2+}$-influx channels are restricted to the ciliary membrane [36]; see Fig. 3(A and $\mathrm{B})$. Restriction of the $\mathrm{Ca}^{2+}$ signal guarantees a maximal effect for signalling specifically within the cilium and, therefore, is economic. The number of $\mathrm{Ca}^{2+}$ ions required to mediate ciliary reversal has been estimated as $\sim 700$ by energy dispersive X-ray microanalysis [48], whereas somewhat higher or lower values have been derived from electrophysiology, depending on the conditions $[49,50]$. Spillover deeper into the cell soma is avoided by binding 


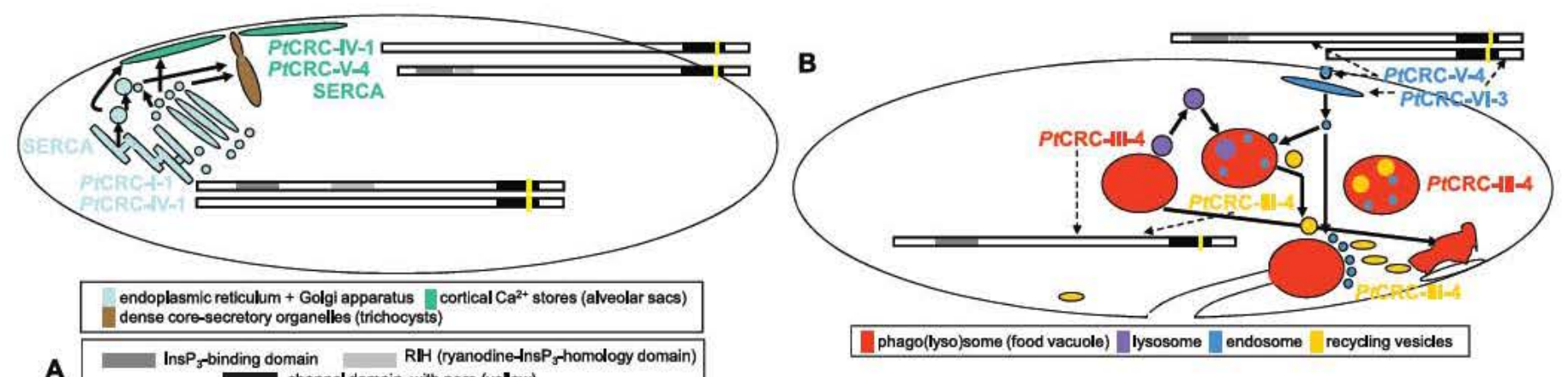

A

InsP $P_{5}$-binding domain $\quad$ RIH (ryanodine-Ins $P_{5}$-homology domain)

phago(lyso)some (food vacuole) lysosome endosome recyding vesicles

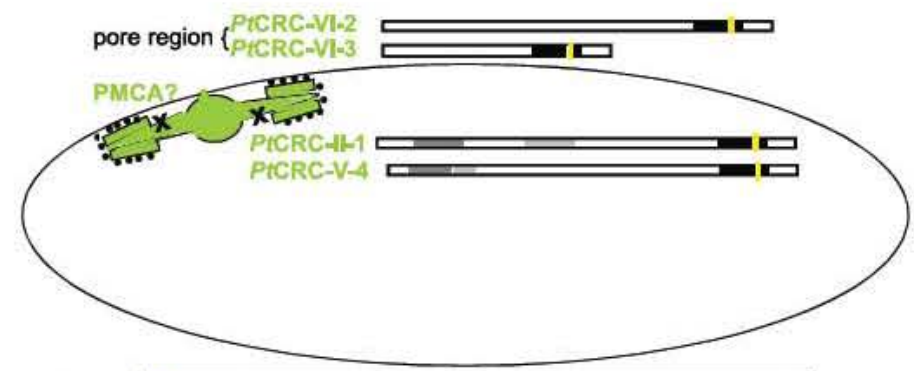

C contractile vacuole complex $\times$ PMCA (plasmamembrane $\left.\mathrm{Ca}^{24}-\mathrm{ATPase}\right)$ ?

Fig. 4. Distribution of PtCRCs in the Paramecium cell. In figs. A-C, roman numbers indicate the PtCRC subfamily, arabic numbers added to the PtCRC channel designation indicate subtypes experimentally localised by antibodies and/or GFP fusion. Note that, beyond the channel domain, the occurrence of some other domains, such as the RIH domain and the Ins $\mathrm{P}_{3}$-biding domain, is quite variable. Vesicle transport is outlined by arrows. (A) Distribution of PtCRCs along the secretory pathway. Note the occurrence of two different channel types, PtCRC-I and PtCRC-IV, in the endoplasmic reticulum, whereas no PtCRCs have been recognised so far in the Golgi apparatus and in trichocysts. One of these channels, PtCRC-IV-1, also occurs in alveolar sacs where it has been identified as a RyR-LP and as an initiator of Ca ${ }^{2+}$ signalling, during exocytosis stimulation, in a SOC-type mechanism. Alveolar sacs also contain a channel of type PtCRC-V-4. Its function, specifically the significance of its Ins $\mathrm{P}_{3}$-binding domain, is unknown. (B) Distribution of PtCRCs along the endocytotic and phagocytotic pathway. All stages of food vacuoles/phago(lyso)somes are equipped with PtCRC-III, as are different sorts of recycling vesicles. These originate in part from the cytoproct and in part from advanced stages of food vacuoles during their migration through the cell (cyclosis). Remarkably parasomal sacs (coated pits) contain a PtCRC of a different type (PtCRC-V) and remarkably this is different from that seen in terminal cisternae (early endosomes), i.e. PtCRC-VI which is a rather short molecule. For details, see text. (C) PtCRCs in the contractile vacuole complex. In peripheral parts its smooth spongiome contains PtCRC-II and PtCRC-V, whereas PtCRC-VI-2 and PtCRC-VI-3 are restricted to the small region at the cell surface containing the exocytosis site ("pore") for the periodic release of vacuole fluid. This may be facilitated by the nearby PtCRC-VI channels, whereas PtCRC-II has been specified as a genuine $\mathrm{IP}_{3} \mathrm{R}$ serving for reflux of some of the Ca ${ }^{2+}$ that has been sequestered and which is predominantly released by the organelle. The occurrence of a PMCA in the organelle is uncertain.

to calmodulin and centrin. This occurs still in the cilium where centrin activates the voltage-dependent $\mathrm{Ca}^{2+}$-influx channels [51]. Also in the cilia of ciliates, $\mathrm{Ca}^{2+} /$ calmodulin exerts a negative feedback on $\mathrm{Ca}^{2+}$-influx channels and, thus, terminates $\mathrm{Ca}^{2+}$-influx [52]. Not only the depolarisation $[32,33]$, but also the hyperpolarisation response is based on $\mathrm{Ca}^{2+}$ and calmodulin by regulating channel conductances $[38,39]$.

It was the Paramecium cell where termination of the depolarisation response by formation of $\mathrm{a} \mathrm{Ca}^{2+} /$ calmodulin complex has been detected [52]. Remarkably, the on/off switch of voltage dependent $\mathrm{Ca}^{2+}$-channels by $\mathrm{a} \mathrm{Ca}^{2+} /$ calmodulin complex in the ciliary membrane is conserved up to pyramidal cells of the mammalian brain [53] where they serve for long-term potentiation (learning). In ciliates, the intraciliary $\mathrm{Ca}^{2+}$ signal does normally not spill into the cell soma [48] but vanishes by binding to centrin contained in the cell cortex [54]; here, centrin mainly contributes to the formation of a regularly arranged filamentous cortical network, the infraciliary lattice [55]. Centrin is endowed, also in ciliates, not only with EFhand high affinity $\mathrm{Ca}^{2+}$ binding loops $[56,57]$, but also with acidic aminoacid clusters for high capacity $\mathrm{Ca}^{2+}$ binding [56]. Presence of a plasmamembrane $\mathrm{Ca}^{2+}$-ATPase (PMCA, $\mathrm{Ca}^{2+}$ pump) is ascertained for the somatic (non-ciliary) cell membrane [58], its occurrence in cilia, though likely, is still under debate [59]. Its activity, like that of the SERCA pump of alveolar sacs [60], may be much less efficient than the secondary active $\mathrm{Ca}^{2+}$ transport coupled to $\mathrm{H}^{+}$-ATPase activity in other parts of the cell $[27,40]$.
A $\mathrm{K}^{+}$current carries the hyperpolarization-induced receptor potential [61] and then highly $\mathrm{Ca}^{2+}$-selective hyperpolarizationactivated channels in the somatic membrane are activated. They peak within one ciliary stroke, i.e. within $20-80 \mathrm{~ms}$ [62]. In total it looks as if ciliary reversal, thanks to the more distinct localisation of the underlying $\mathrm{Ca}^{2+}$-channels, is more precisely regulated at the organelle level than enhanced forward swimming - escape from an attack being more important than feeding.

\subsection{Exocytosis sites for trichocysts}

These sites, characterised in Fig. 6, are also regularly arranged (Figs. 1 and 2). In freeze-fractures they are highly organised, with particle pattern [63] whose molecular identity has not been clearly elucidated as yet. According to gene silencing experiments they must dispose of SNARE proteins for membrane fusion to occur $[64,65]$, as well as of a sensor responding to the $\left[\mathrm{Ca}^{2+}\right]_{i}$ increase that is also mandatory for exocytotic membrane fusion [22]. However, the $\mathrm{Ca}^{2+}$ sensor still requires identification. Low capacity/high sensitivity sensors of the type known from metazoans, i.e. synaptotagmin-type molecules with two $\mathrm{C} 2$ domains, are not found in the Paramecium database [65]. Here, proteins with eight, rather than two $\mathrm{C} 2$-domains are found. They thus resemble another type of $\mathrm{Ca}^{2+}$ sensors, the "extended synaptotagmin-LPs" (ESyts) $[66,67]$ that substitute for synaptotagmin in some mammalian cells. 

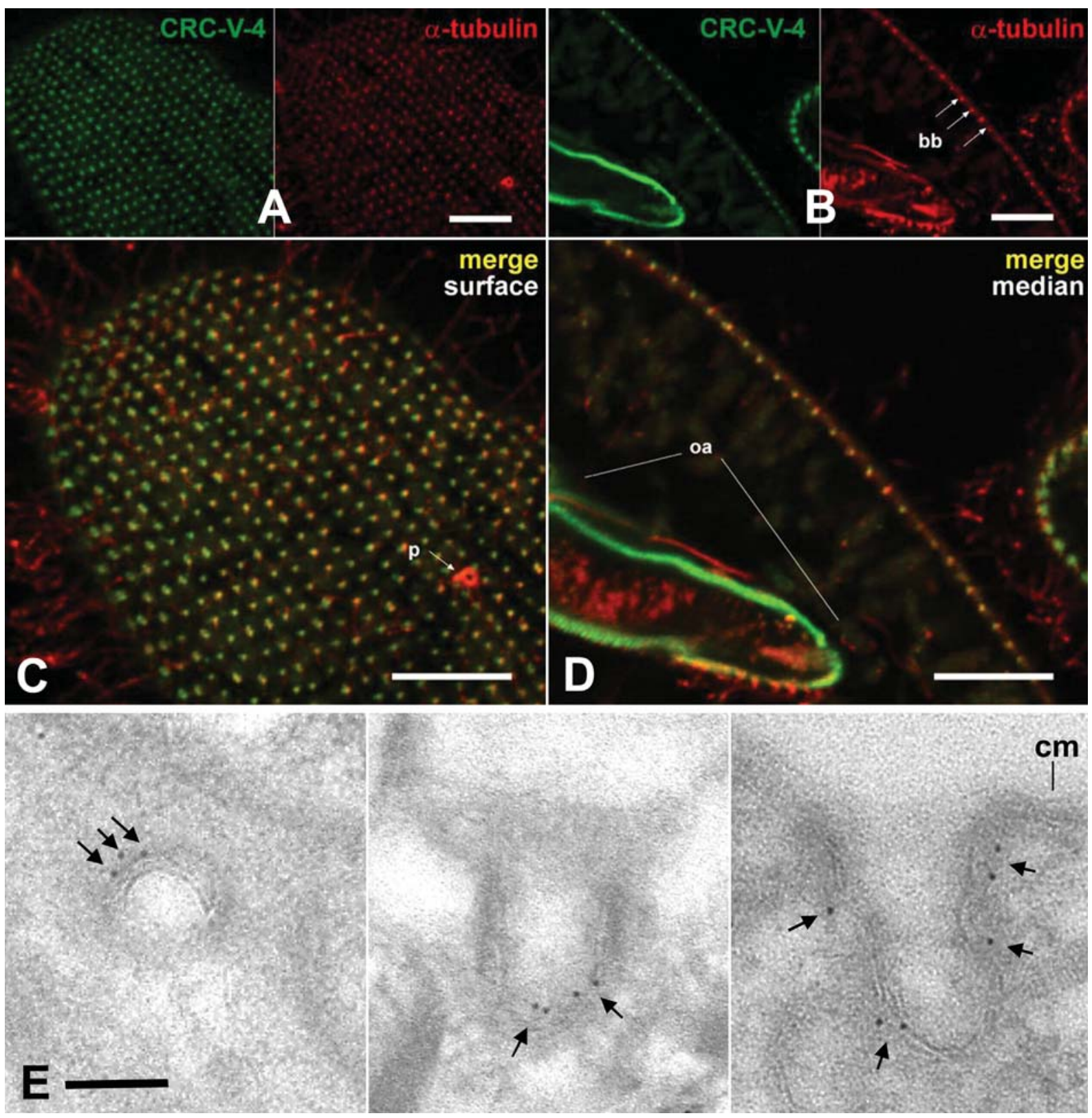

Fig. 5. Immuno-localisation of PtCRC-V-4 to coated pits (parasomal sacs). From Ladenburger and Plattner [28]. (A-D) Confocal laser scanning microscopy of immunefluorescence localisation of PtCRC-V-4 channels using monospecific antibodies (green) together with antibodies against $\alpha$-tubulin (red). To be compared with Figs. 1 and 4B for gross orientation. (A and C) Surface view with red and green signal in close association because parasomal sacs are closely associated with ciliary basal bodies (bb). Note absence of green label from the pore (p) of the contractile vacuole complex. (B and D) median view, again with close association of red and green signal. Moreover, the oral apparatus (oa) is flanked by green label indicating presence of PtCRC-V-4. Bars $=10 \mu \mathrm{m}$. (E) Electron microscopic immuno-gold (arrows) localisation of PtCRC-V-4 at parasomal sacs in cross-section (left), oblique section (middle) and longitudinal/median section (right); pm = plasmamembrane. Bar=0.1 $\mu \mathrm{m}$.

In Paramecium, exocytosis is paralleled by a cortical $\left[\mathrm{Ca}^{2+}\right]_{i}$ increase, as has been analysed by fluorochrome analysis [68], energy-dispersive X-ray microanalysis [69] and by electrophysiology [4]. In this context, none of the ciliary membrane channels play a role. During exocytosis stimulation $\mathrm{Ca}^{2+} /$ calmodulin activated currents at the somatic cell membrane have been recorded to monitor $\mathrm{Ca}^{2+}$ signals as close to the cell membrane as possible. The duration of one single current event accompanying one exocytosis event was $\sim 50 \mathrm{~ms}, t_{1 / 2}=21 \mathrm{~ms}$. This corresponds the analysis time which was available also for fast confocal fluorochrome analysis and for quenched-flow/X-ray microanalysis. With $\left[\mathrm{Ca}^{2+}\right]_{0}$ reduced to slightly below $\left[\mathrm{Ca}^{2+}\right]_{i}$ at rest, the signal is weak and causes only a small extent of trichocyst release. All three methods converged in the conclusion that the activation mechanism underlying $\mathrm{Ca}^{2+}$ signalling during trichocyst exocytosis involves a store-operated $\mathrm{Ca}^{2+}$-influx, SOC $[22,23]$. A full exocytotic response requires both, $\mathrm{Ca}^{2+}$ release in a first step, influx as a second step and another release as the third step (Fig. 6), all steps being very tightly coupled.

Since the explosive discharge of trichocyst contents by decondensation from a carrot- to a needle-shape, also depends on extracellular $\mathrm{Ca}^{2+}[70]$, experiments were repeated with mutants devoid of any $\mathrm{Ca}^{2+}$-influx in presence of normal $\left[\mathrm{Ca}^{2+}\right]_{0}[71]$. A $\mathrm{Ca}^{2+}$-induced $\mathrm{Ca}^{2+}$ release, CICR, could thus be excluded. Evidently SOC may be older than CICR. This is supported by the following experiments.

$\mathrm{Ca}^{2+}$ release from alveolar sacs as a first step, before additional $\mathrm{Ca}^{2+}$ entry, can be seen also in energy-dispersive X-ray microanalysis, but only when $\left[\mathrm{Ca}^{2+}\right]_{o}$ is reduced to near resting $\left[\mathrm{Ca}^{2+}\right]_{i}$ levels 


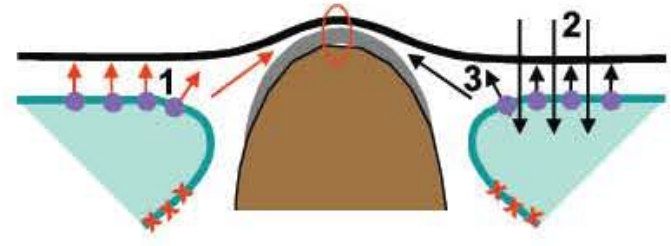

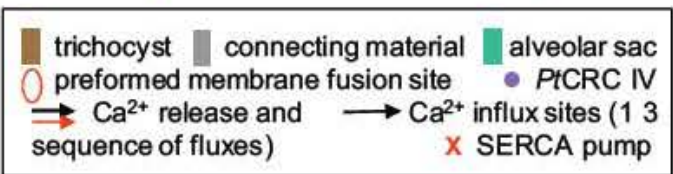

Fig. 6. Trichocyst docking site flanked by alveolar sacs tightly attached to the cell membrane. Alveolar sacs contain PtCRC-IV channels which have been identified as RyR-LPs. Upon exocytosis stimulation, $\mathrm{Ca}^{2+}$ is first released from alveolar sacs by the PtCRC-IV channels (step 1), followed by a store-operated $\mathrm{Ca}^{2+}$-influx (SOC) into the sacs (step 2), and a second wave of $\mathrm{Ca}^{2+}$ release from alveolar sacs (step 3). Sequences $1-3$ of $\mathrm{Ca}^{2+}$ fluxes are tightly coupled in time and, thus, can be ascertained only with special techniques indicated in the text. Channels type PtCRC-V-4 in alveolar sacs, as indicated in Fig. 4A, are of unknown function and, therefore, omitted here. Note the occurrence of SERCA in domains facing the cell centre, opposite to RyR-LPs/PtCRC-IV channels whose arrangement guarantees $\mathrm{C} \mathrm{Ca}^{2+}$ flux directed to exocytosis sites.

and when $\mathrm{Ca}^{2+}$ in the medium is rapidly exchanged for $\mathrm{Sr}^{2+}$ during stimulation in quenched flow/cryofixation/X-ray microanalysis experiments [69]. The latter experiments show $\mathrm{Sr}^{2+}$ in alveolar sacs, whereas the $\mathrm{Ca}^{2+}$ signal in the sacs has vanished. How such rapid entry of $\mathrm{Ca}^{2+}$ (or of $\mathrm{Sr}^{2+}$ in the substitution experiments) into alveolar sacs is possible, to make $\mathrm{Ca}^{2+}$ depletion unrecognisable under standard conditions, is not known, particularly since reuptake by the SERCA pump is unexpectedly slow [72]. Later on a similar phenomenon, called "direct mass-action mechanism" has also been reported for a chicken lymphocyte cell line [73].

In Paramecium, both, endogenous and exogenous $\mathrm{Ca}^{2+}$ is spilled over exocytosis sites (Fig. 6) and, thus, maximal stimulation of exocytosis is achieved. In addition, increased $\left[\mathrm{Ca}^{2+}\right]_{0}$ during stimulation also accelerates resealing of exocytosis sites (exocytosis-coupled endocytosis) and internalisation of empty "ghosts" [63].

The CRCs involved in $\mathrm{Ca}^{2+}$ release from alveolar sacs during exocytosis are of type PtCRC-IV. They have structural characteristics of RyR-LPs and are activated not only by the RyR agonists, caffeine and 4-chloro-meta-cresol, but, in addition, also by the polyamine secretagogue, aminoethyldextrane, AED [41]. $\mathrm{Ca}^{2+}$ is spilled over exocytosis sites, where it has to reach a local concentration of $\sim 5 \mu \mathrm{M}$, as determined by $\mathrm{Ca}^{2+}$ chelators of different affinity [68]. This construction principle for a site-directed $\mathrm{Ca}^{2+}$ flow within the narrow space between the plasmamembrane and a cortical $\mathrm{Ca}^{2+}$ store (alveolar sacs in ciliates) is found not only in ciliates, but also in some metazoan cells up to mammalians. However, molecules communicating store emptying and mediating $\mathrm{Ca}^{2+}$-influx in a SOCtype mechanism, such as Stim and Orai [74], have not been found in ciliates, neither by us [75] nor by others [76]. Thus, the molecular basis of this part of $\mathrm{Ca}^{2+}$ signalling in ciliates remains open for the time being. Currently several alternative molecules are discussed for linking cortical compartments to the cell membrane, as outlined previously [75]. In addition Giordano et al. [77] have assigned such a role to synaptotagmin-LPs whose presence in Paramecium has been mentioned above. It may well be that Orai/Stim are used for dynamically rearranged cortical $\mathrm{Ca}^{2+}$ stores, in contrast to stationary cortical stores, such as alveolar sacs.

In essence, a site-directed $\mathrm{Ca}^{2+}$ flow is required to achieve trichocyst exocytosis. The regular arrangement of relevant components (Figs, 1,2 and 6) appears mandatory. Trichocyst exocytosis sites somehow recall a skeletal muscle cell because of the tight linkage of a subplasmalemmal $\mathrm{Ca}^{2+}$ store (terminal cisternae of the sarcoplasmic reticulum) to the cell membrane. It also recalls the end plate of a motor neuron, considering the regular arrangement of intramembranous particles representing $\mathrm{Ca}^{2+}$-influx channels in close association with exocytosis sites [78]. With this regard it would be desirable to know the signification of the regular particle arrays seen in freeze-fractures at trichocyst exocytosis sites as well as of their dynamic rearrangement during exocytotic membrane fusion $[23,65]$. What is the relation between the structural organisation and $\mathrm{Ca}^{2+}$ signalling?

The flood of $\mathrm{Ca}^{2+}$ over trichocyst exocytosis sites can be calculated from the values determined by X-ray microanalysis. If it were restricted to the subplasmalemmal space it would exceed by several orders of magnitude the $\left[\mathrm{Ca}^{2+}\right]_{l}$ actually needed (when available in free form) at exocytosis sites [22]. This situation, i.e. the requirement of an unexpectedly strong $\mathrm{Ca}^{2+}$-flux, strikingly resembles that in endocrine cells [79]. In chromaffin cells the actual distance of $\mathrm{Ca}^{2+}$-influx channels from the potential fusion site of a docked dense core-vesicle determines actual fusion capacity [45] and only a fraction of chromaffin granules attached to the cell membrane is released upon depolarisation [80]. Just like in motor end plates and in nerve terminals [81], ciliated protozoan cells have optimised this principle already early on by epigenetically determined coassembly of both, $\mathrm{Ca}^{2+}$ signal generation and membrane fusion sites as targets. Consider that strict coordination between local $\mathrm{Ca}^{2+}$ signalling and local trichcocyst exocytosis is vital, as it is mandatory for warding off with maximal efficiency the deadly attacks by predatory cells $[82,83]$.

So far unknown is the function of a second CRC type, PtCRC$\mathrm{V}-4$, also in alveolar sacs, where these channels are enriched near contact sites between adjacent sacs [28]. Unexpectedly PtCRC-V4 contains an Ins $\mathrm{P}_{3}$-binding domain. Particularly intriguing is also the occurrence of these CRCs in parasomal sacs (see below).

Even though the calcium leakage rate determined with ${ }^{45} \mathrm{Ca}^{2+}$ is rather high in unstimulated Paramecium cells $[84,85]$ spontaneous trichocyst release is relatively scarce [43]. No trichocyst exocytosis takes place when $\left[\mathrm{Ca}^{2+}\right]$ in the medium is suddenly increased in the medium, even though this yields a strong overall fluorochrome signal [4]. The same is true of $\mathrm{Ca}^{2+}$ injection $[22,68]$. All this supports the concept of strictly localised microdomain $\mathrm{Ca}^{2+}$ signalling, based on co-assembly of components, including $\mathrm{Ca}^{2+}$-channels.

\subsection{Endoplasmic reticulum}

The endoplasmic reticulum contain s not only PtCRC-I-1, but also PtCRC-IV-1 type channels [28]. The first type contains an InsP $\mathrm{P}_{3}$ binding domain, in contrast to the second type (Fig. 4A). Since the latter are also present in alveolar sacs, where they represent the main type of CRCs (see above), this supports the hypothesis that alveolar sacs are formed by vesicle transport from the endoplasmic reticulum. This pathway has been found by in vivo-tracing of the transport of green fluorescent protein-labelled SERCA molecules [86]. The same can be derived from studies where vesicle delivery has been suppressed by silencing of the SNARE-specific chaperone, $\mathrm{N}$-ethylmaleimide sensitive factor, NSF [87]. This transport must encompass a selective step since the endoplasmic reticulum contains a calreticulin-LP, whereas the alveolar sacs are endowed with a calsequestrin-LP [88]. This distinction was achieved by immunocytochemistry using distinct antibodies selective for either one of these luminal high capacity/low affinity $\mathrm{Ca}^{2+}$-binding proteins. This finding also underscores the similarity of the alveolar sacs with the sarcoplasmic reticulum and, moreover, indicates selective transport for coassembly of proper components in specific organelles that are relevant for $\mathrm{Ca}^{2+}$ signalling. 

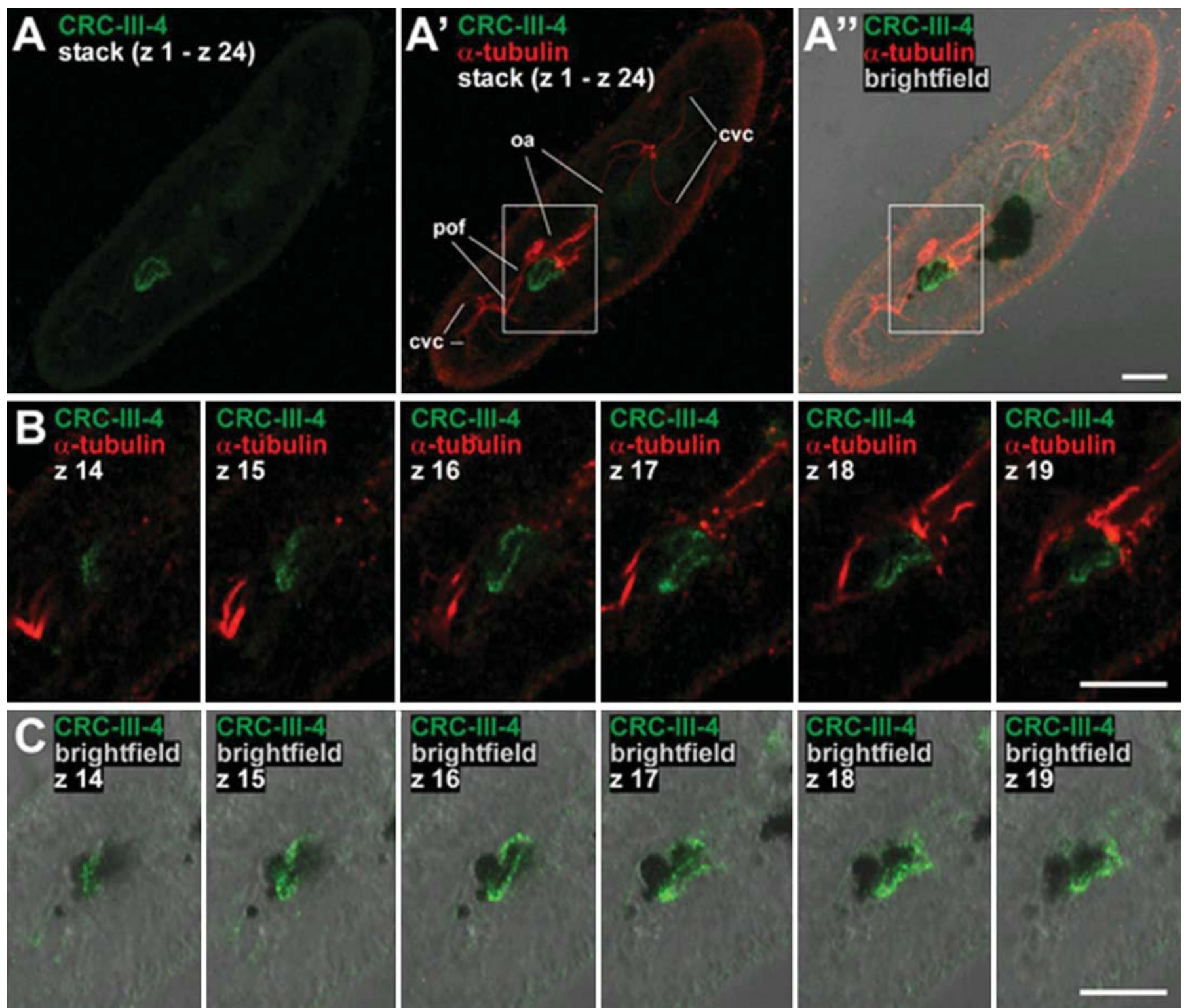

z 19
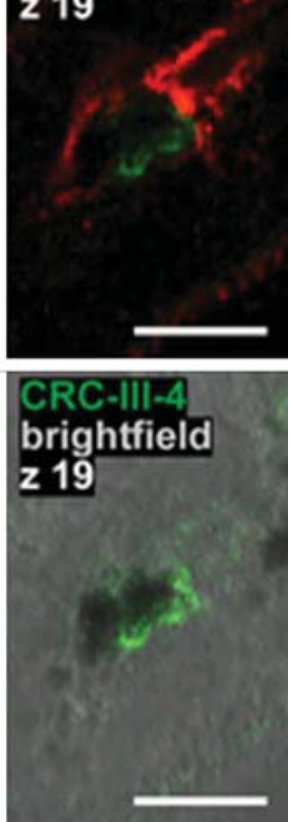

Fig. 7. Confocal laser scanning microscopy of immune-fluorescence localisation of PtCRC-III-4 channels using monospecific antibodies (green) together with antibodies against \&-tubulin (red). Phagosomes are black due to filling with Indian ink. To be compared with Fig. 4B. From Ladenburger and Plattner [28]. Bars $=10 \mu \mathrm{m}$. (A-A\& and B) Tubulin staining outlines the trafficking avenue along postoral fibres (pof), between the cytoproct and the oral apparatus (oa) whose cilia are also stained, as are cilia on the cell surface and the outlines of the contractile vacuole complex (cvc). Confocal planes (z) and pile-up (z1-z24) as indicated. (C) Brightfield image with Indian ink-filled food vacuole with superimposed immunostaining for PtCRC-III-4 contained in aggregates of recycling vesicles (as confirmed by electron microscopy [not shown]). Note intense interaction between recycling vesicles and the food vacuole.

\subsection{Endo- and phagocytotic pathways}

Epigenetic programing is also evident for the precise positioning of the oral cavity and the cytoproct, though less directly for the mobile, small and large vesicular components of the endocytotic and phagocytotic cycle. They all contain PtCRC-III channels (Fig. 4B). This is documented by confocal immune-fluorescence microscopy in Fig. 7. It may provide $\mathrm{Ca}^{2+}$ for the multiple interactions and fusions which the many types of vesicles can undergo [10]. As mentioned, other types of CRCs are contained in coated pits (parasomal sacs) and in early endosomes that are located near ciliary basal bodies (Figs. 1, 4B and 5) and contain PtCRC-V-4 and PtCRC-VI-3, respectively [28]. One can think of several mechanisms to explain that CRCs (just like SNARE proteins) cannot in all cases be traced throughout a specific trafficking pathway; for instance, this can depend on the actual retention rate of a specific membrane protein. These two channel types also occur along the oral cavity [28]; in this part of the cell one also has to take into account the occurrence of endocytotic structures and of small alveoli (see R.D. Allen at http://www.5.pbrc.hawaii.edu/allen/ [3]).

\subsection{Contractile vacuole complex}

The pores of the two contractile vacuoles, whose location is also epigenetically predetermined, undergo periodic constitutive exocytosis of the kiss-and-run type in $\sim 10 \mathrm{~s}$ intervals. The filling state may be sensed by mechanosensitive channels [27], but CRCs of type PtCRC-VI-2 and PtCRC-VI-3, both restricted to the pore area [28] as indicated in Fig. 4C, could also provide $\mathrm{Ca}^{2+}$ locally. (Note, however, that the expression of PtCRC-VI-3 is variable, eventually in fragmented or abortive form.) PtCRC-V-4 is another candidate, as it is also present in this region of the contractile vacuole complex. Its 
InsP $\mathrm{P}_{3}$-binding domain is shorter than in the most abundant form, PtCRC-II, occurring over large parts of the contractile vacuole complex [28]. No details are known about the function of PtCRC-type channels in the contractile vacuole complex except PtCRC-II, as to be discussed now.

In the following we have to consider the most elaborate labyrinth of a 3D-meshwork of membrane-enveloped narrow tubules, the so-called spongiome. This part sequesters $\mathrm{H}^{+}$ions into the lumen, enabled by its endowment with a V-type $\mathrm{H}^{+}$-ATPase $[89,90]$; in the electron microscope these molecules mediate a decorated appearance and this part is, therefore, called the "decorated spongiome". The sequestration of $\mathrm{Ca}^{2+}$ is coupled to the activity of the $\mathrm{H}^{+}$-ATPase $[75,91,92]$. In contrast, the smooth spongiome, which on its peripheral part is continuous with the decorated spongiome and on the proximal part directly attached to the collecting canals (feeding into the contractile vacuole), contains $\mathrm{IP}_{3} \mathrm{Rs}$, type PtCRC-II [40]. Here, PtCRC-II type CRCs mediate some spontaneous reflux of $\mathrm{Ca}^{2+}$ from the lumen into the cytosol, be it for fine-tuning of local $\left[\mathrm{Ca}^{2+}\right]_{i}$ and/or to enable internal restructuring of the 3D network of the spongiome [27]. This finding was unexpected insofar as this system continuously and efficiently extrudes not only an excess of water, but also of $\mathrm{Ca}^{2+}[91]$. A comparable capability of spontaneous, constitutive $\mathrm{IP}_{3} \mathrm{R}$ activation has then also been described for a chicken lymphocyte cell line [93].

\section{The pore region of the PtCRCs molecules in comparison to mammalian $\mathrm{IP}_{3} \mathrm{Rs}$ and RyRs}

One aspect concerning PtCRCs, types $\mathrm{IP}_{3} \mathrm{Rs}$ and RyR-LPs, emerging from our work with Paramecium is the formation of the pore region by six transmembrane domains [28]. It thus agrees with the general assumption of 6 transmembrane domains for the $\mathrm{IP}_{3} R$, but deviates from the tentative assumption of only 4 [94], 6-8 [95] or 4-10 [96] for RyRs, as summarised in the reviews cited. More recently another type of bioinformatic analysis led to the same conclusion, i.e. 6 transmembrane domains, for the skeletal muscle RyR [97] and this now seems to be tacitly accepted also by others [98]. Furthermore, the general assignment of a sequence Gly-Val-GlyAsp to the selectivity filter of $\mathrm{IP}_{3}$ Rs and Gly-Ile-Gly-Asp to that of RyRs [99] is not applicable to lower eukaryotes; not only CRCs of Paramecium [28], but also those in lower metazoans show these two motives alternatively [12].

There is also evidence for the occurrence of receptors for CADPR and NAADP in Paramecium, founded on microinjection and on NAADP binding studies [75], but neither any molecular identity nor any specific localisation can be assigned to the respective CRCs as yet.

\section{Conclusions}

In Paramecium, $\mathrm{Ca}^{2+}$-influx from the outside medium and/or mobilised from internal stores can contribute to signalling. Any $\mathrm{Ca}^{2+}$ effect on ciliary activity is regulated exclusively by $\mathrm{Ca}^{2+}-$ influx; specifically voltage-dependent $\mathrm{Ca}^{2+}$-channels, restricted to the ciliary membrane, serve for the reversal of the ciliary beat. Hyperpolarisation-induced accelerated forward swimming also involves $\mathrm{Ca}^{2+}$ signals, though not primarily in the cilium. Many different types of PtCRCs, i.e. release channels related to $\mathrm{IP}_{3} \mathrm{Rs}$ and/or RyRs, are scattered over a multitude of vesicular compartments. For instance, $\mathrm{Ca}^{2+}$ required for trichocyst exocytosis is provided by a SOC mechanism, starting with $\mathrm{Ca}^{2+}$ release from alveolar sacs which is superimposed by $\mathrm{Ca}^{2+}$-influx without any recognisable delay. The underlying PtCRC, type PtCRC-IV, is a RyR-related channel restricted to the endoplasmic reticulum and alveolar sacs. Since trichocyst exocytosis sites and cilia are only $\sim 1.7-2.0 \mu \mathrm{m}$ apart, spillover phenomena have to be restricted by properly positioned $\mathrm{Ca}^{2+}$ binding proteins, such as centrin. Therefore, normally no $\mathrm{Ca}^{2+}$ flux from the cilium into the cell soma occurs. However, a remarkable $\mathrm{Ca}^{2+}$ spillover into cilia does occur during massive synchronous exocytosis stimulation, thus enforcing escape from predator attacks [83]. Hereby depolarisation as a trigger is bypassed. Not only cilia and alveolar sacs, but also parasomal sacs (coated pits) and early endosomes are endowed with specific PtCRCs. The localisation of all these compartments is also under strict epigenetic control, though with unknown functional implications. Rather, such coassembly may represent not only a prerequisite to, but also the result of epigenetically controlled $\mathrm{Ca}^{2+}$ signalling. PtCRC-II-type CRCs, localised to the pair of contractile vacuole complexes are $\mathrm{IP}_{3} \mathrm{Rs}$. These serve for the extrusion of an excess of water and $\mathrm{Ca}^{2+}$. Their PtCRC-II can serve for fine-tuning of cytosolic $\mathrm{Ca}^{2+}$ by partial reflux and probably also for reversible restructuring processes within the spongiome. Finally compartments of the phagocytotic system and vesicles serving for membrane recycling also possess distinct CRCs, type PtCRC-III. The pathway of some of the vesicles (those shuttling from the cytoproct to the cytopharynx) is also epigenetically fixed within the Paramecium cell. All this differential distribution of PtCRCs has its counterpart in a comparable distribution pattern of SNARE proteins [65]. Together with other components, whose localisation is also under epigenetic control, the regular design of the Paramecium cell makes it highly efficient in vesicle trafficking and $\mathrm{Ca}^{2+}$ signalling already at a low level of evolution.

\section{Acknowledgement}

The author's work cited herein has been supported by the German Research Council.

\section{References}

[1] R.D. Allen, Cytology, in: H.-D. Görtz (Ed.), Paramecium, Springer-Verlag, Berlin, Heidelberg, 1988, pp. 4-40

[2] H. Plattner, My favorite cell - Paramecium, Bioessays 24 (2002) 649-658.

[3] R.D. Allen, Available at: http://www.5.pbrc.hawaii.edu/allen/

[4] C. Erxleben, N. Klauke, M. Flötenmeyer, M.-P. Blanchard, C. Braun, H. Plattner, Microdomain $\mathrm{Ca}^{2+}$ activation during exocytosis in Paramecium cells. Superposition of local subplasmalemmal calcium store activation by local $\mathrm{Ca}^{2+}$ influx, J. Cell Biol. 136 (1997) 597-607.

[5] J. Beisson, T.M. Sonneborn, Cytoplasmic inheritance of the organization of the cell cortex in Paramecium aurelia, Proc. Natl. Acad. Sci. U. S. A. 53 (1965) 275-282.

[6] J. Beisson, Preformed cell structure and cell heredity, Prion 2 (2008) 1-8.

[7] J. Frankel, Dimensions of control of cortical patterns in Euplotes - role of preexisting structure, clonal life-cycle, and genotype, J. Exp. Zool. 183 (1973) 71-94.

[8] D. Wloga, J. Frankel, From molecules to morphology: cellular organization of Tetrahymena thermophila, Methods Cell Biol. 109 (2012) 83-140.

[9] A.K. Fok, R.D. Allen, Membrane flow in the digestive cycle of Paramecium, in: H. Plattner (Ed.), Membrane Traffic in Protozoa, JAI Press, Greenwich (CONN), London (GB), 1993, pp. 311-337.

[10] R.D. Allen, A.K. Fok, Membrane trafficking and processing in Paramecium, Int. Rev. Cytol. 198 (2000) 277-318

[11] X. Cai, Unicellular $\mathrm{Ca}^{2+}$ signaling 'toolkit' at the origin of metazoa, Mol. Biol. Evol. 25 (2008) 1357-1361.

[12] H. Plattner, A. Verkhratsky, $\mathrm{Ca}^{2+}$ signalling early in evolution - all but primitive, J. Cell Sci. 126 (2013) 2141-2150.

[13] H. Plattner, Calcium regulation in the protozoan model, Paramecium tetraurelia, J. Eukaryot. Microbiol. 61 (2014) 95-114.

[14] A.-D. Wright, D.H. Lynn, Maximum ages of ciliate lineages estimated using a small subunit rRNA molecular clock: crown eukaryotes date back to the paleoproterozoic, Arch. Protistenk. 148 (1997) 329-341.

[15] E.J. Douzery, E.A. Snell, E. Bapteste, F. Delsuc, H. Philippe, The timing of eukaryotic evolution: does a relaxed molecular clock reconcile proteins and fossils? Proc. Natl. Acad Sci. U S. A. 101 (2004)15386-15391.

[16] C. Berney, J. Pawlowski, A molecular time-scale for eukaryote evolution recalibrated with the continuous microfossil record, Proc. R. Soc. B Biol. Sci. 273 (2006) 1867-1872

[17] S.M. Adl, A.G. Simpson, C.E. Lane, J. Lukes, D. Bass, S.S. Bowser, M.W. Brown, F. Burki, M. Dunthorn, V. Hampl, A. Heiss, M. Hoppenrath, E. Lara, L. Le Gall, D.H. Lynn, H. McManus, E.A. Mitchell, S.E. Mozley-Standridge, L.W. Parfrey, J. Pawlowski, S. Rueckert, R.S. Shadwick, C.L. Schoch, A. Smirnov, F.W. Spiegel, 
The revised classification of eukaryotes, J. Eukaryot. Microbiol. 59 (2012) 429-493.

[18] D. He, O. Fiz-Palacios, C.-J. Fu, J. Fehling, C.-C. Tsai, S.L. Baldauf, An alternative root for the eukaryote tree of life, Curr. Biol. 24 (2014) 465-470.

[19] B. Alberts, Impact factor distortions, Science 340 (2013) 787.

[20] M. Simon, H. Plattner, Unicellular eukaryotes as models in cell and molecular biology: a critical appraisal of their past and future value, Int. Rev. Cell Mol Biol. 309 (2014) 141-198.

[21] N. Stelly, J.P. Mauger, M. Claret, A. Adoutte, Cortical alveoli of Paramecium: vast submembranous calcium storage compartment, J. Cell Biol. 113 (1991) 103-112.

[22] H. Plattner, N. Klauke, Calcium in ciliated protozoa: sources, regulation, and calcium-regulated cell functions, Int. Rev. Cytol. 201 (2001) 115-208.

[23] H. Plattner, J. Hentschel, Sub-second cellular dynamics: time-resolved electron microscopy and functional correlation, Int. Rev. Cytol. 255 (2006) 133-176

[24] M.A. Sleigh, Encounters with cilia, in: K. Hausmann, R. Radek (Eds.), Cilia and Flagella, Ciliates and Flagellates, Schweizerbart Science Publishers, Stuttgart, Germany, 2014, pp. 121-131.

[25] Y. Nakaoka, H. Tanaka, F. Oosawa, $\mathrm{Ca}^{2+}$-dependent regulation of beat frequency of cilia in Paramecium, J. Cell Sci. 65 (1984) 223-231.

[26] H. Machemer, Electrophysiology, in: H.-D. Görtz (Ed.), Paramecium, SpringerVerlag, Berlin, Heidelberg, 1988, pp. 185-215.

[27] H. Plattner, The contractile vacuole complex of protists - new cues to function and biogenesis, Crit. Rev. Microbiol. (2013), http://dx.doi.org/10.3109/ 1040841X.2013.821650.

[28] E.-M. Ladenburger, H. Plattner, Calcium-release channels in Paramecium. Genomic expansion, differential positioning and partial transcriptional elimination, PLoS ONE 6 (11) (2011) e27111.

[29] C.R. Artalejo, J.R. Henley, M.A. McNiven, H.C. Palfrey, Rapid endocytosis coupled to exocytosis in adrenal chromaffin cells involves $\mathrm{Ca}^{2+}$, GTP, and dynamin but not clathrin, Proc. Natl. Acad. Sci. U. S. A. 92 (1995) 8328-8332.

[30] M.M. Lai, J.J. Hong, A.M. Ruggiero, P.E. Burnett, V.I. Slepnev, P. De Camilli, S.H. Snyder, The calcineurin-dynamin 1 complex as a calcium sensor for synaptic vesicle endocytosis, J. Biol. Chem. 274 (1999) 25963-25966.

[31] R.R. Preston, Genetic dissection of $\mathrm{Ca}^{2+}$-dependent ion channel function in Paramecium, Bioessays 12 (1990) 273-281.

[32] C. Kung, R.R. Preston, M.E. Maley, K.Y. Ling, J.A. Kanabrocki, B.R. Seavey, Y Saimi, In vivo Paramecium mutants show that calmodulin orchestrates membrane responses to stimuli, Cell Calcium 13 (1992) 413-425.

[33] Y. Saimi, C. Kung, Calmodulin as an ion channel subunit, Annu. Rev. Physiol. 64 (2002) 289-311.

[34] Y. Saimi, C. Kung, Behavioral genetics of Paramecium, Annu. Rev. Genet. 21 (1987) 47-65.

[35] D.L. Prole, C.W. Taylor, Identification and analysis of putative homologues of mechanosensitive channels in pathogenic protozoa, PLOS ONE 8 (6) (2013) e66068.

[36] H. Machemer, A. Ogura, Ionic conductances of membranes in ciliated and deciliated Paramecium, J. Physiol. 296 (1979) 49-60.

[37] H. Machemer, P.F.M. Teunis, Sensory motor coupling and motor responses, in: K. Hausmann, P.C. Bradbury (Eds.), Ciliates: Cells and Organisms, Gustav Fischer Verlag, Stuttgart, 1996, pp. 379-402.

[38] J.L. Van Houten, Chemosensory transduction in Paramecium, Eur. J. Protistol. 34 (1998) 301-307

[39] W.E. Bell, R.R. Preston, J. Yano, J.L. Van Houten, Genetic dissection of attractant-induced conductances in Paramecium, J. Exp. Biol. 210 (2007) 357-365.

[40] E.-M. Ladenburger, I. Korn, N. Kasielke, T. Wassmer, H. Plattner, An Ins (1,4,5) $\mathrm{P}_{3}$ receptor in Paramecium is associated with the osmoregulatory system, J. Cell Sci. 119 (2006) 3705-3717.

[41] E.-M. Ladenburger, I.M. Sehring, I. Korn, H. Plattner, Novel types of $\mathrm{Ca}^{2+}$ release channels participate in the secretory cycle of Paramecium cells, Mol. Cell. Biol. 29 (2009) 3605-3622.

[42] O. Dellis, A.M. Rossi, S.G. Dedos, C.W. Taylor, Counting functional inosito 1,4,5-trisphosphate receptors into the plasma membrane, J. Biol. Chem. 283 (2008) 751-755.

[43] H. Plattner, H. Matt, H. Kersken, B. Haacke, R. Stürzl, Synchronous exocytosis in Paramecium cells. I. A novel approach, Exp. Cell Res. 151 (1984) 6-13.

[44] E. Neher, Vesicle pools and $\mathrm{Ca}^{2+}$ microdomains: new tools for understanding their roles in neurotransmitter release, Neuron 20 (1998) 389399.

[45] U. Becherer, T. Moser, W. Stühmer, M. Oheim, Calcium regulates exocytosis at the level of single vesicles, Nat. Neurosci. 6 (2003) 846-853.

[46] S.L. Tamm, Ctenophores and termites - systems for motility, in: K. Hausmann, R. Radek (Eds.), Cilia and Flagella, Ciliates and Flagellates, Schweizerbart Science Publishers, Stuttgart, Germany, 2014, pp. 147-171.

[47] H.A. Praetorius, K.R. Spring, Removal of the MDCK cell primary cilium abolishes flow sensing, J. Membr. Biol. 191 (2003) 69-76.

[48] M.R. Husser, M. Hardt, M.-P. Blanchard, J. Hentschel, N. Klauke, H. Plattner One-way calcium spill-over during signal transduction in Paramecium cells: from the cell cortex into cilia, but not in the reverse direction, Cell Calcium 36 (2004) 349-358

[49] R. Eckert, Bioelectric control of ciliary activity, Science 176 (1972) 473-481.

[50] D. Oertel, S.J. Schein, C. Kung, Separation of membrane currents using a Paramecium mutant, Nature 268 (1977) 120-124.
[51] K. Gonda, K. Oami, M. Takahashi, Centrin controls the activity of the ciliary reversal coupled voltage-gated $\mathrm{Ca}^{2+}$ channels $\mathrm{Ca}^{2+}$-dependently, Biochem. Biophys. Res. Commun. 362 (2007) 170-176.

[52] P. Brehm, R. Eckert, Calcium entry leads to inactivation of calcium channel in Paramecium, Science 202 (1978) 1203-1206.

[53] I.B. Levitan, It is calmodulin after all! Mediator of the calcium modulation of multiple ion channels, Neuron 22 (1999) 645-648.

[54] I.M. Sehring, C. Klotz, J. Beisson, H. Plattner, Rapid downregulation of the $\mathrm{Ca}^{2+}$ signal after exocytosis stimulation in Paramecium cells: essential role of a centrin-rich filamentous cortical network, the infraciliary lattice, Cell Calcium 45 (2009) 89-97.

[55] C. Klotz, N. Garreau de Loubresse, F. Ruiz, J. Beisson, Genetic evidence for a role of centrin-associated proteins in the organization and dynamics of the infraciliary lattice in Paramecium, Cell Motil. Cytoskel. 38 (1997) 172-186.

[56] K. Kim, M. Son, J.B. Peterson, D.L. Nelson, $\mathrm{Ca}^{2+}$-binding proteins of cilia and infraciliary lattice of Paramecium tetraurelia: their phosphorylation by purified endogenous $\mathrm{Ca}^{2+}$-dependent protein kinases, J. Cell Sci. 115 (2002) 1973-1984.

[57] D. Gogendeau, C. Klotz, O. Arnaiz, A. Malinowska, M. Dadlez, N. Garreau de Loubresse, F. Ruiz, F. Koll, J. Beisson, Functional diversification of centrins and cell morphological complexity, J. Cell Sci. 121 (2008) 65-74.

[58] N.L. Elwess, J.L. Van Houten, Cloning and molecular analysis of the plasma membrane $\mathrm{Ca}^{2+}$-ATPase gene in Paramecium tetraurelia, J. Eukaryot. Microbiol. 44 (1997) 250-257.

[59] J. Yano, A. Rajendran, M.S. Valentine, M. Saha, B.A. Ballif, J.L. Van Houten, Proteomic analysis of the cilia membrane of Paramecium tetraurelia, J. Proteomics 78 (2013) 113-122

[60] K. Hauser, N. Pavlovic, R. Kissmehl, H. Plattner, Molecular characterization of a sarco(endo)plasmic reticulum $\mathrm{Ca}^{2+}$-ATPase gene from Paramecium tetraurelia and localization of its gene product to sub-plasmalemmal calcium stores, Biochem. J. 334 (1998) 31-38.

[61] Y. Naitoh, R. Eckert, Ionic mechanisms controlling behavioral responses of Paramecium to mechanical stimulation, Science 164 (1969) 963-965.

[62] R.R. Preston, Y. Saimi, C. Kung, Calcium current activated upon hyperpolarization of Paramecium tetraurelia, J. Gen. Physiol. 100 (1992) 233-251.

[63] H. Plattner, C. Braun, J. Hentschel, Facilitation of membrane fusion during exocytosis and exocytosis-coupled endocytosis and acceleration of ghost detachment in Paramecium by extracellular calcium. A quenchedflow/freeze-fracture analysis, J. Membr. Biol. 158 (1997) 197-208.

[64] R. Kissmehl, C. Schilde, T. Wassmer, C. Danzer, K. Nuehse, K. Lutter, H. Plattner Molecular identification of 26 syntaxin genes and their assignment to the different trafficking pathways in Paramecium, Traffic 8 (2007) 523-542.

[65] H. Plattner, Membrane trafficking in protozoa: SNARE proteins, $\mathrm{H}^{+}$-ATPase, actin, and other key-players in ciliates, Int. Rev. Cell Mol. Biol. 280 (2010) 79-184.

[66] S.W.Min, W.P. Chang, T.C. Südhof, E-Syts, a family of membranous $\mathrm{Ca}^{2+}$-sensor proteins with multiple C2 domains, Proc. Natl. Acad. Sci. U. S. A. 104 (2007) 3823-3828.

[67] S. Martens, H.T. McMahon, Mechanisms of membrane fusion: disparate players and common principles, Nat. Rev. Mol. Cell Biol. 9 (2008) 543-556.

[68] N. Klauke, H. Plattner, Imaging of $\mathrm{Ca}^{2+}$ transients induced in Paramecium cells by a polyamine secretagogue, J. Cell Sci. 110 (1997) 975-983.

[69] M. Hardt, H. Plattner, Sub-second quenched-flow/X-ray microanalysis shows rapid $\mathrm{Ca}^{2+}$ mobilization from cortical stores paralleled by $\mathrm{Ca}^{2+}$ influx during synchronous exocytosis in Paramecium cells, Eur. J. Cell Biol. 79 (2000) 642-652.

[70] M. Bilinski, H. Plattner, H. Matt, Secretory protein decondensation as a distinct, $\mathrm{Ca}^{2+}$-mediated event during the final steps of exocytosis in Paramecium cells, J. Cell Biol. 88 (1981) 179-188.

[71] I. Mohamed, N. Klauke, J. Hentschel, J. Cohen, H. Plattner, Functional and fluorochrome analysis of an exocytotic mutant yields evidence of store-operated $\mathrm{Ca}^{2+}$ influx in Paramecium, J. Membr. Biol. 187 (2002) 1-14.

[72] I. Mohamed, M. Husser, I. Sehring, J. Hentschel, C. Hentschel, H. Plattner, Refilling of cortical calcium stores in Paramecium cells: in situ analysis in correlation with store-operated calcium influx, Cell Calcium 34 (2003) 87-96.

[73] B. Narayanan, M.N. Islam, D. Bartelt, R.S. Ochs, A direct mass-action mechanism explains capacitative calcium entry in Jurkat and skeletal L6 muscle cells, J. Biol. Chem. 278 (2003) 44188-44196.

[74] M.M.Wu, R.M. Luik, R.S. Lewis, Some assembly required: constructing the elementary units of store-operated $\mathrm{Ca}^{2+}$ entry, Cell Calcium 42 (2007) 163-172.

[75] H. Plattner, I.M. Sehring I.K. Mohamed, K. Miranda, W. De Souza, R. Billington, A. Genazzani, E.-M. Ladenburger, Calcium signaling in closely related protozoan groups (Alveolata): non-parasitic ciliates (Paramecium, Tetrahymena) vs. parasitic Apicomplexa (Plasmodium, Toxoplasma), Cell Calcium 51 (2012) 351-382.

[76] D.L. Prole, C.W. Taylor, Identification of intracellular and plasma membrane calcium channel homologues in pathogenic parasites, PLoS ONE 6 (10)(2011) e26218.

[77] F. Giordano, Y. Saheki, O. Idevall-Hagren, S.F. Colombo, M. Pirruccello, I. Milosevic, E.O. Gracheva, S.N. Bagriantsev, N. Borgese, P. De Camilli, PI(4,5)P2dependent and $\mathrm{Ca}^{2+}$-regulated ER-PM interactions mediated by the extended synaptotagmins, Cell 153 (2013) 1494-1509.

[78] J.E. Heuser, T.S. Reese, M.J. Dennis, Y. Jan, L. Jan, L. Evans, Synaptic vesicle exocytosis captured by quick freezing and correlated with quantal transmitte release, J. Cell Biol. 81 (1979) 275-300. 
[79] A.W. Henkel, W. Almers, Fast steps in exocytosis and endocytosis studied by capacitance measurements in endocrine cells, Curr. Opin. Neurobiol. 6 (1996) 350-357.

[80] H. Plattner A.R. Artalejo, E. Neher, Ultrastrucural organization of bovine chromaffin cell cortex - analysis by cryofixation and morphometry of aspects pertinent to exocytosis, J. Cell Biol. 139 (1997) 1709-1717.

[81] R.G. Zhai, H.J. Bellen, The architecture of the active zone in the presynaptic nerve terminal, Physiology 19 (2004) 262-270.

[82] T. Harumoto, A. Miyake, Defensive function of trichocysts in Paramecium, J. Exp. Biol. 260 (1991) 84-92.

[83] G. Knoll, B. Haacke-Bell, H. Plattner, Local trichocyst exocytosis provides an efficient escape mechanism for Paramecium cells, Eur. J. Protistol. 27 (1991) 381-385.

[84] J.L. Browning, D.L. Nelson, Biochemical studies of the excitable membrane of Paramecium aurelia. I. ${ }^{45} \mathrm{Ca}^{2+}$ fluxes across resting and excited membrane, Biochim. Biophys. Acta 448 (1976) 338-351.

[85] D. Kerboeuf, J. Cohen, $\mathrm{A} \mathrm{Ca}^{2+}$ influx associated with exocytosis is specifically abolished in a Paramecium exocytotic mutant, J. Cell Biol. 111 (1990) 2527-2536.

[86] K. Hauser, N. Pavlovic, N. Klauke, D. Geissinger, H. Plattner, Green fluorescent protein-tagged sarco(endo)plasmic reticulum $\mathrm{Ca}^{2+}$-ATPase overexpression in Paramecium cells: isoforms, subcellular localization, biogenesis of cortical calcium stores and functional aspects, Mol. Microbiol. 37 (2000) 773787.

[87] R. Kissmehl, M. Froissard, H. Plattner, M. Momayezi, J. Cohen, NSF regulates membrane traffic along multiple pathways in Paramecium, J. Cell Sci. 115 (2002) 3935-3946.

[88] H. Plattner, A. Habermann, R. Kissmehl, N. Klauke, I. Majoul, H.-D. Söling, Differential distribution of calcium-stores in Paramecium cells. Occurrence of a subplasmalemmal store with a calsequestrin-like protein, Eur. J. Cell Biol. 72 (1997) 297-306.

[89] A.K. Fok, K. Yamauchi, A. Ishihara, M.S. Aihara, M. Ishida, R.D. Allen, The vacuolar-ATPase of Paramecium multimicronucleatum: gene structure of the B subunit and the dynamics of the V-ATPase-rich osmoregulatory membranes, J. Eukaryot. Microbiol. 49 (2002) 185-196.

[90] T. Wassmer, I.M. Sehring, R. Kissmehl, H. Plattner, The V-ATPase in Paramecium: functional specialization by multiple gene isoforms, Pflugers Arch. Eur. J. Physiol. 457 (2009) 599-607.

[91] C. Stock, H.K. GrØnlien, R.D. Allen, The ionic composition of the contractile vacuole fluid of Paramecium mirrors ion transport across the plasma membrane, Eur. J. Cell Biol. 81 (2002) 505-515.

[92] H.K Grønlien, C. Stock, M.S, Aihara, R.D. Allen, Y. Naitoh, Relationship between the membrane potential of the contractile vacuole complex and its osmoregulatory activity in Paramecium multimicronucleatum, J. Exp. Biol. 205 (2002) 3261-3270

[93] C. Cárdenas, R.A. Miller, I. Smith, T. Bui, J. Molgó, M. Müller, H. Vais, K.-H. Cheung, J. Yang, I. Parker, C.B. Thompson, M.J. Birnbaum, K.R. Hallows, J.K. Foskett, Essential regulation of cell bioenergetics by constitutive $\mathrm{InsP}_{3}$ receptor $\mathrm{Ca}^{2+}$-transfer to mitochondria, Cell 142 (2010) 270-283.

[94] A.J. Williams, D.J. West, R. Sitsapesan, Light at the end of the $\mathrm{Ca}^{2+}$-release channel tunnel: structures and mechanisms involved in ion translocation in ryanodine receptor channels, Q. Rev. Biophys. 34 (2001) 61-104.

[95] R. Zalk, S.E. Lehnart, A.R. Marks, Modulation of the ryanodine receptor and intracellular calcium, Annu. Rev. Biochem. 76 (2007) 367-385.

[96] S.L. Hamilton, Ryanodine receptors, Cell Calcium 38 (2005) 253-260.

[97] S. Ramachandran, A. Chakraborty, L. Xu, Y. Mei, M. Samsó, N.V. Dokholyan, G. Meissner, Structural determinants of skeletal muscle ryanodine receptor gating, J. Biol. Chem. 288 (2013) 6154-6165.

[98] A.C. Gomez, N. Yamaguchi, Two regions of the ryanodine receptor calcium channel are involved in $\mathrm{Ca}^{2+}$-dependent inactivation, Biochemistry 53 (2014) 1373-1379.

[99] D.F. Boehning, Molecular architecture of the inositol 1,4,5-trisphosphate receptor pore, Curr. Top. Membr. 66C (2010) 191-207.

[100] M. Bilinski, H. Plattner, R. Tiggemann, Isolation of surface membranes from normal and exocytotic mutant strains of Paramecium tetraurelia. Ultrastructural and biochemical characterization, Eur. J. Cell Biol. 24 (1981) 108-115. 